This item was submitted to Loughborough's Research Repository by the author.

Items in Figshare are protected by copyright, with all rights reserved, unless otherwise indicated.

\title{
Overview of the Malawi energy situation and A PESTLE analysis for sustainable development of renewable energy
}

\section{PLEASE CITE THE PUBLISHED VERSION}

http://dx.doi.org/10.1016/j.rser.2014.05.050

\section{PUBLISHER}

(C) Elsevier Ltd

\section{VERSION}

AM (Accepted Manuscript)

\section{PUBLISHER STATEMENT}

This paper was accepted for publication in the journal Renewable and Sustainable Energy Reviews and the definitive published version is available at https://doi.org/10.1016/j.rser.2014.05.050.

\section{LICENCE}

CC BY-NC-ND 4.0

\section{REPOSITORY RECORD}

Zalengera, Collen, Richard Blanchard, Philip Eames, Alnord M. Juma, Maxon L. Chitawo, and Kondwani T. Gondwe. 2019. "Overview of the Malawi Energy Situation and A PESTLE Analysis for Sustainable Development of Renewable Energy". figshare. https://hdl.handle.net/2134/17650. 


\title{
Overview of the Malawi energy situation and A PESTLE analysis for sustainable development of renewable energy
}

Collen Zalengera ${ }^{\mathrm{a}}{ }^{1}$, Richard E. Blanchard ${ }^{\mathrm{a}}$, Philip C. Eames $^{\mathrm{a}}$, Alnord M. Juma ${ }^{\mathrm{b}}$, Maxon L. Chitawo ${ }^{\mathrm{b}}$, Kondwani T. Gondwe ${ }^{b}$

${ }^{a}$ Centre for Renewable Energy Systems Technology - School of Electronic, Electrical and

Systems Engineering, Loughborough University, United Kingdom

${ }^{\mathrm{b}}$ Mzuzu University, Private bag 201, Luwinga Mzuzu 2, Malawi

Emails: C.Zalengera@lboro.ac.uk, R.E.Blanchard@lboro.ac.uk, P.C.Eames@lboro.ac.uk, alnord.juma@yahoo.com,maxonxhitawo@yahoo.co.uk,kondwanithapasila@yahoo.com

Tel: +441509635339

\begin{abstract}
This paper presents a review of the energy situation in Malawi and discusses renewable energy options that can strengthen Malawi's energy supply and energy security. The paper reviews the availability of renewable energy resources namely solar, wind, biomass, hydro, and geothermal in Malawi; and explores the potential of upscaling and broadening the applications of the existing renewable energy technologies. The paper also analyses challenges facing Malawi's energy sector, and presents a framework for sustainable delivery of renewable energy systems based on political, economic, social, technological, legal and environmental factors (PESTLE). About 89 percent of the Malawi's energy is sourced from traditional biomass mainly fuel wood which has led to fuel wood demand exceeding sustainable wood supply. Only 8 percent of the population in Malawi have access to electricity; however installed capacity of electricity generation is lower than demand which leads to load shedding by the supplier and consequently electricity supply in Malawi is unreliable. Certainly, solar, nontraditional biomass (crop residues and forest residues not burnt on three stone fireplaces, and biogas) and hydro can contribute significantly to Malawi's inadequate and unreliable energy supply. There is also potential for wind and geothermal in the country but further resource mapping is required to comprehensively determine these resources. Although the Malawi Energy Policy lays out steps towards improving the energy supply in the country, unreliable financing mechanisms for large scale energy projects, shortage of trained human resource, lack of coordination among local institutions, unclear regulation enforcement and sometimes political governance impede sustainable delivery of energy projects in Malawi.
\end{abstract}

Keywords: Malawi, energy situation, renewable energy, PESTLE analysis.

\section{Introduction}

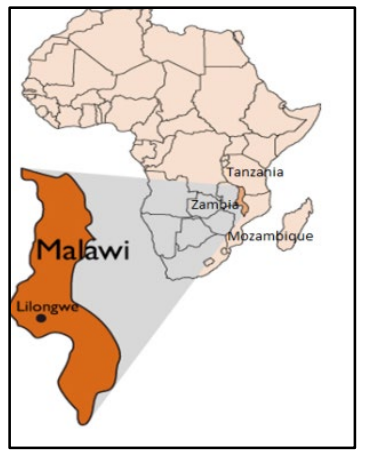

Malawi is a land-locked country located in southern Africa: bordered by Tanzania to the north, Zambia to the west and Mozambique to the south and east as shown in Figure 1. An extract of the country's demography is shown in Table 1.

Table 1: Demography Extract for Malawi

\begin{tabular}{|l|l|}
\hline Parameter & Unit \\
\hline Total Area & $118,484 \mathrm{~km}^{2}[1]$ \\
\hline Population & 15.38 million (2011 estimates) [2] \\
\hline Population growth rate & 2.8 percent [3] \\
\hline Access to grid electricity & $\begin{array}{l}8 \text { percent }(20 \text { percent urban, } 1 \\
\text { percent rural) [4] }\end{array}$ \\
\hline GDP per capita (PPP) & US\$870 (2011 estimates) [2] \\
\hline
\end{tabular}

\footnotetext{
${ }^{1}$ The present address until September 2014: Centre for Renewable Energy Systems Technologies, School of Electronic, Electrical and Systems Engineering, Loughborough University, United Kingdom; Email: C.Zalengera@lboro.ac.uk. Permanent address is: Mzuzu University, Private bag 201, Luwinga, Mzuzu 2; Email: czalengera@mzuni,ac.mw
} 
Figure 1: Location of Malawi

The country earns 80 percent of export earnings from agriculture, which also provides over 85percent of employment and contributes about 35 percent of GDP, second to Services at 46 percent; manufacturing contributes only 19 percent of GDP [5]. About 40 percent of Malawians live below US\$1 per person per day [5]. Despite the social growth reported in [6], there is a unanimous consensus in the country that low access to and poor modern energy limit economic growth, investments in industrial activities, and improvement of living standards. The overall aim of this paper is to review the energy situation facing Malawi in light of limited access to modern energy services and the ideal need to develop these services making use of renewable energy technologies. Therefore, the objectives are to present data on the current energy mix for Malawi, to review the renewable energy resources that are available, to outline the current energy policies for Malawi and to analyse challenges to the development of energy provision in the context of political, economic, social, technological, and legal factors. Previous work, for example in [7], discussing the energy situation of Malawi is limited to efforts in the development of renewable energy technologies in Malawi. It is also observed that such work lack detailed data for discussion of the potential of renewable energy technologies in Malawi; this gap is addressed in this paper. In addition, a PESTLE framework for delivery of renewable energy systems discussed in this paper is a new contribution to the renewable energy literature for Malawi. The paper is structured as follows: Section 2 presents the installed capacities of energy technologies; Malawi's energy balance is presented in section 3, and section 4 outlines the Malawi Energy Policy; whilst the potential renewable energy resources, challenges for the energy supply industry, and the PESTLE analysis for delivery of renewable energy technologies are discussed in sections 5, 6, and 7 respectively. The conclusion is set out in section 8 .

\section{Installed Capacities of Energy Technologies in Malawi}

Table 2 shows estimated installed capacities of the energy technologies. Estimates of solar photovoltaic (PV), wind and biogas are based on informal surveys and varying unpublished information due to lack of reliable information management system for energy statistics for the country.

Table 2: Installed Capacities of Energy Technologies in Malawi

\begin{tabular}{|l|l|}
\hline Technology & Installed Capacity \\
\hline Large-scale hydro & $281.5 \mathrm{MW}^{\mathrm{a}}[8,9]$ \\
\hline Small-scale hydro & $\sim 4.6 \mathrm{MW}[8,9]$ \\
\hline Thermal electricity (fossil fuel driven turbines) & $2.15 \mathrm{MW}[8,9]$ \\
\hline Solar PV & $\begin{array}{l}\text { No data but }>5000 \text { installations } \\
(\sim 1 \mathrm{MW})\end{array}$ \\
\hline Wind & No data but $<1 \mathrm{MW}$ \\
\hline Biogas & $\begin{array}{l}\text { Around } 30 \text { fixed dome }\left(\sim 120 \mathrm{~m}^{3}\right. \\
\text { mainly using cow dung; one } 12 \mathrm{~m}^{3} \\
\text { using human waste })\end{array}$ \\
\hline Ethanol & 18 million litres per annum $[9]$ \\
\hline
\end{tabular}

a an additional 64MW is under construction, expected to be commissioned in the last quarter of 2013; this will bring the total installed capacity of large hydro to $345.5 \mathrm{MW}$.

\section{Malawi's Energy Balance}

Figure 2 shows the energy consumption by sectors and Figure 3 shows the overall energy balance for Malawi. 


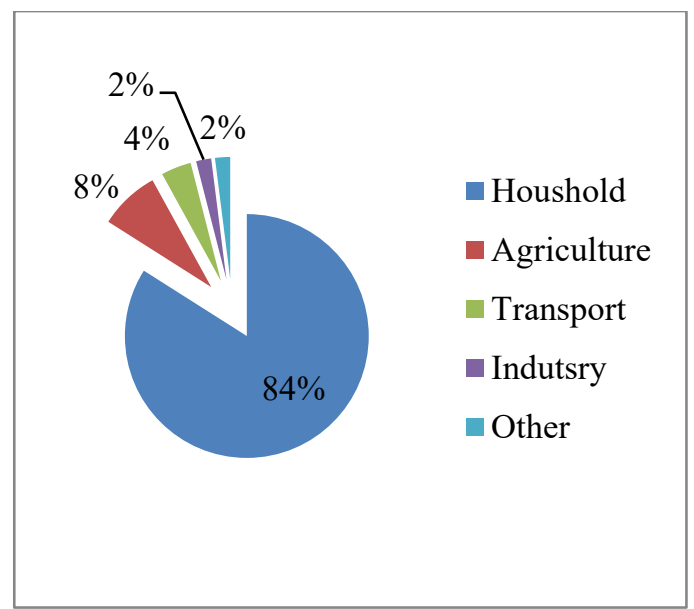

Figure 2: Energy Consumption by Sectors [9]

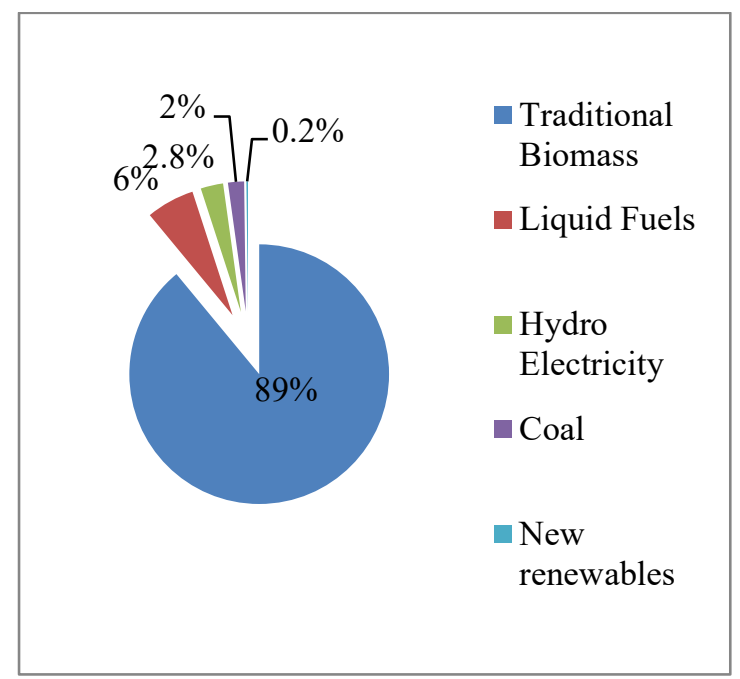

Figure 3: Energy Balance for Malawi-adapted from $[9,10]$

It can be seen from Figure 2 and Figure 3 that households contribute significantly to the energy demand and that traditional biomass is the major source of energy. Traditional biomass constitutes 91 percent of household energy consumption with 52 percent of the biomass energy used in firewood form, 7 percent as residues and 41 percent as charcoal [9]. Overdependence on traditional biomass has resulted in wood demand surpassing sustainable wood supply by more than 3.7 million tonnes per annum [11]. Electricity is supplied by a sole state owned Electricity Supply Cooperation of Malawi (ESCOM) which is also the grid-network operator. Hydropower contributes 99 percent of grid electricity; 98 percent of this is generated along the one Shire River. The electricity generation capacity is lower than the demand: with only 8 percent of Malawians accessing grid electricity services $[5,12]$, the country still experiences blackouts due to inevitable load-shedding carried out by the electricity utility company. Petroleum products are exclusively imported, albeit the country produces ethanol which is, in one part, intended for blending with petrol in the ratio of 20:80 [9]. Coal is locally produced and is used in industries such as tobacco processing, and breweries but some of the coal is imported from Mozambique: Industries located in southern Malawi are closer to Mozambique and find it easier to get the coal from the neighbouring country than from Malawi coal mines which are closer to Tanzania and consequently export some of the coal to Tanzania. New renewable energy technologies in Malawi include off-grid solar photovoltaic systems, small off-grid wind turbines and fixed-dome biogas systems mainly installed in rural communities. Since 2010 the country also mines Uranium, over 670 tonnes in 2011 [13] increasing yearly, but this is just for export; there are no nuclear power plants in Malawi yet. Paraffin and firewood are the major sources of lighting and cooking respectively. Figure 4 and Figure 5 show the energy balance for lighting and cooking at household level. 


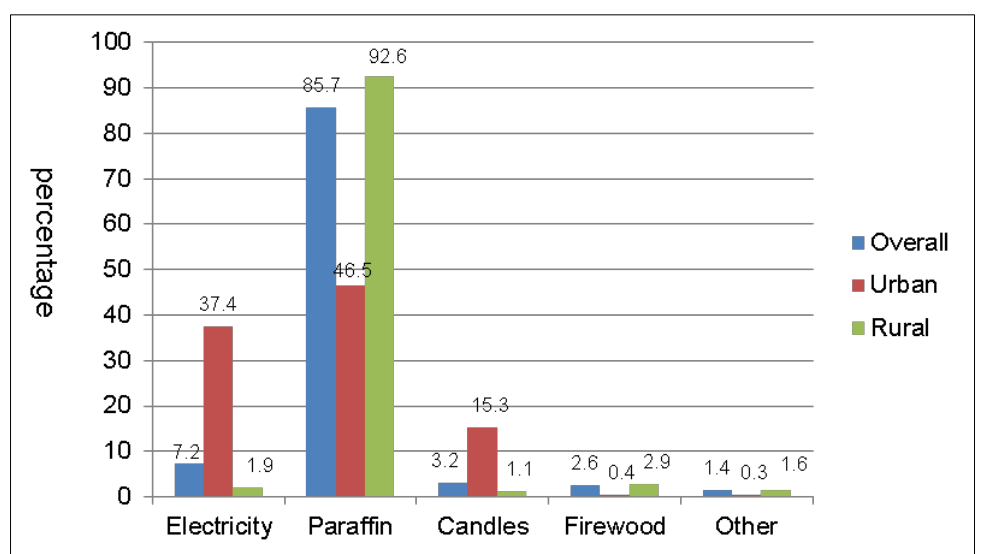

Figure 4: Malawi’s Energy Balance for Lighting-adapted from [3]

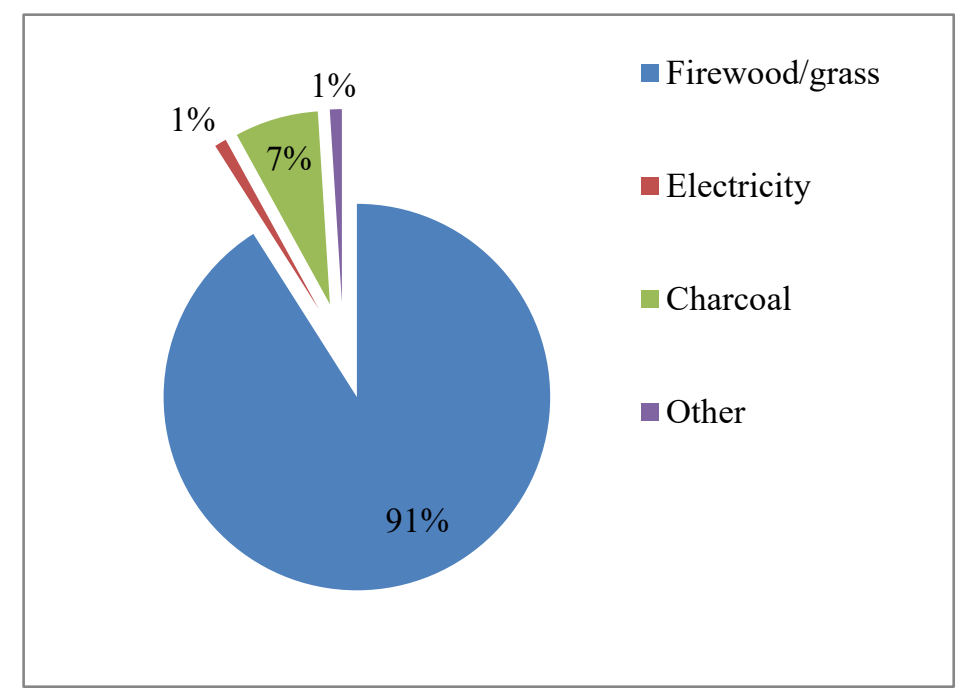

Figure 5: Malawi's Energy Balance for Cooking [9]

The statistics shown in Figure 4 and Figure 5 may have changed, but not significantly, from the time the information was published in 2008 and 2003 respectively; there were no reliable source of revised statistics until 2013 except for electricity figures in Figure 4 which stood at 20 percent in the urban and 1percent in the rural in 2011. To avert the underdeveloped energy balance and to provide reliable energy supply for industrial investment and improved sustainable livelihoods; increasing access to modern energy services such as electricity and development of alternative energy services to traditional biomass and paraffin, and complementary energy generation systems to the existing hydropower generation are crucial. The section below outlines the position of the Malawi Energy Policy towards improving the energy balance and energy supply.

\section{Malawi's Energy Policy}

Malawi's Energy Policy highlights the energy supply shortages already discussed. The Energy Policy attributes the energy supply problems to three factors as outlined in the Malawi Vision 2020 [14] also listed below.

i. Inadequate, unaffordable, unreliable and inaccessible electricity due to monopolistic structures, under-developed services, poor management, lack of competition and cultural inertia;

ii. Over dependence on imported and relatively high cost petroleum products ; and

iii. Overdependence on fuel wood largely produced from indigenous forests with aggregate consumption exceeding levels of sustainable fuel wood yields by about 30 per cent.

The Energy Policy aims to address the energy supply problems by:

i. Improving efficiency and effectiveness of the commercial energy supply industries;

ii. Improving the security and reliability of energy supply systems;

iii. Increasing access to affordable and modern energy services; and

iv. Improving energy sector governance; and mitigating environmental, safety, and health impacts of energy production and utilization. 
The policy goal is therefore to increase the share of modern energy sources driving Malawi's economy; targeting a balance of 50 percent modern energy and 50 percent traditional biomass by 2020 compared to 93 percent traditional biomass and 7 per cent modern energy as of 2000 [9]. Figure 6 shows projections for Malawi's energy-mix.

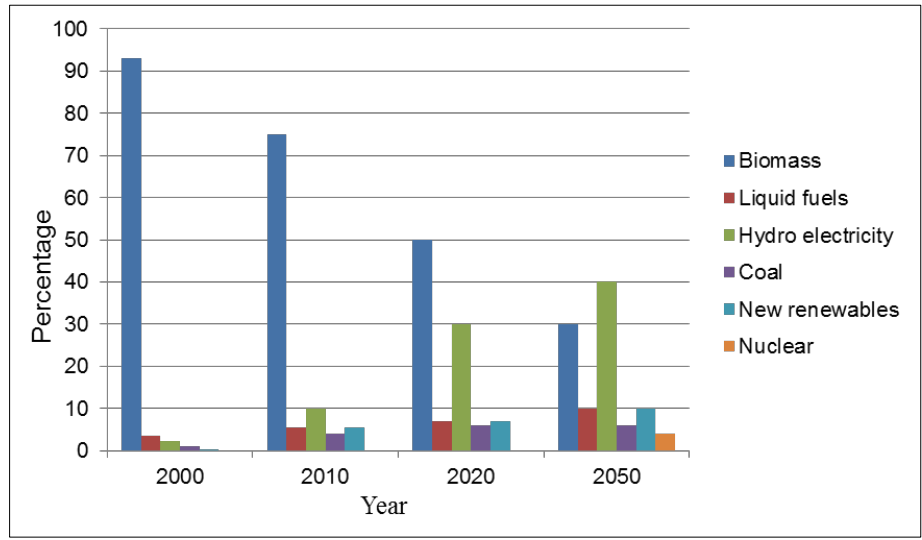

Figure 6 : Energy-Mix Projections-adapted from [9].

In order to achieve the targets shown in Figure 6 , the objectives of Policy as follows:

a) Exploitation of other hydropower sites and developing coal and biomass thermal plants;

b) Interconnection with neighbouring countries;

c) Research and Development (R\&D) into new fuel-ethanol applications;

d) Promotion of the use of affordable alternative energy sources for all fuel wood users through capital subsidies, tax breaks, technical and institutional support for market priming activities involving Renewable Energy Technologies Industries; and

e) Acceleration of rural electrification.

The Government endeavours to source and provide budgetary resources and make reforms in its fiscal policy to ensure that investment in energy generation is attractive and economically competitive; for example, drafting of Feed-In-Tariffs (FIT) to encourage renewable energy generation from Independent Power Producers (IPPs) started in 2011, and in 2012 energy tariffs were reviewed to ensure full recovery of energy investment costs and thus encouraging private sector investment in energy supply business. Nevertheless, by 2011 the energy balance of Malawi comprised around 89 percent biomass compared to the policy target of 75 percent biomass by 2010 , and Owen et al [15] projects that Malawi will still source up to 82 percent of its energy from biomass in 2020 contrary to the 50 percent target in the Energy Policy. The renewable energy resources available in Malawi are therefore discussed below to show a scale of how much they can contribute towards improving the energy situation.

\section{Renewable Energy Resources for Malawi}

\subsection{Solar Energy}

Average solar radiation in Malawi on an horizontal surface is $5.8 \mathrm{kWh} / \mathrm{m}^{2}$ per day [9]. Figure 7 shows monthly solar radiation levels for three weather stations in southern Malawi. Although the stations shown in Figure 7 are from one region of the country, due to challenges of access to information; they represent typical solar radiation levels across the country. 


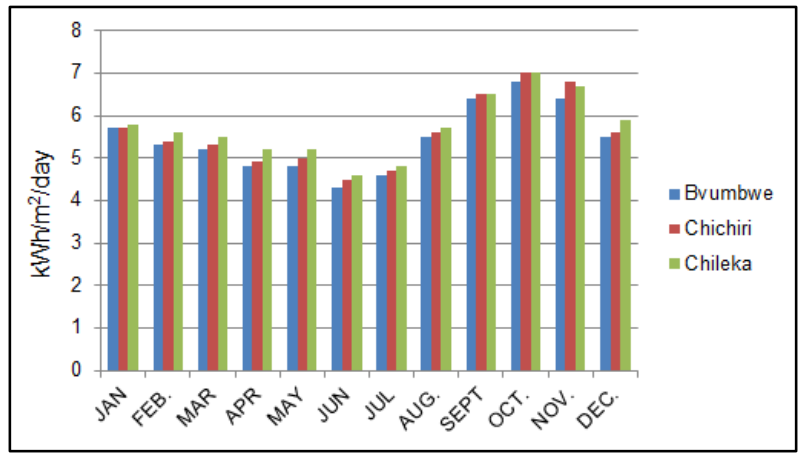

Figure 7: Daily Mean Solar Radiation from three Weather Stations in Malawi-adapted from [16]

The solar radiation levels shown in Figure 7 are viable for both photovoltaic (PV) and thermal applications as discussed in sections 5.1.1 and 5.1.2 that follows.

\subsubsection{Solar photovoltaic}

Based on the average minimum and the average maximum radiation in Figure 7 the potential solar energy ranges from $1,642.5$ to $2,555 \mathrm{kWh} / \mathrm{m}^{2}$ per annum. This can yield over $6,000 \mathrm{GWh}$ per annum, at $15 \%$ module efficiency, from less than $2 \%\left(18 \mathrm{~km}^{2}\right)$ of the country's land area. This is over three times Malawi's electricity generation of 1,900GWh from the grid in 2011 [8]. This shows that it is possible to achieve the $7 \%$ target of new-renewables penetration as outlined in the Malawi Vision 2020 from solar PV alone, subject to land tenure legislation and detailed environmental impact assessment as discussed in section 7.3. Some of the achievements in solar PV in Malawi include six mini-grid PV systems which were implemented as hybrid systems with wind turbines on a scale of $25 \mathrm{~kW}$ each (15kW from Solar PV) supplying about 150 household each [17], whilst standalone PV systems continue to be installed in rural health centres, schools and households since the onset of the Barrier Removal to Renewable Energy Project in Malawi (BaRREM) in 2002 which phased out in 2008. Some charity organisations, for example, World Vision use PV systems for water pumping to supply piped water to rural communities. These efforts can be supplemented with large scale PV systems which can feed into the grid and thus significantly improving the energy security and reducing uncertainties arising from overreliance on the hydropower-generation. The biggest milestone in the application of PV systems in Malawi is the $850 \mathrm{~kW}$ system for the Kamuzu International Airport in Lilongwe to be commissioned before the end of 2013.

\subsubsection{Solar Thermal}

Water heating and cooking contribute a significant amount of the energy demand in the country as evidenced by the load shedding which is usually scheduled at times of cooking and water heating from early mornings to midday and early evenings. Solar thermal applications for water heating and cooking offer great potential to offset a significant amount of the energy demand on the grid power system and thus reduce pressure on the grid network leading to better electricity services for industry and households; Thermal applications also have potential to reduce to reduce demand for fuel wood.; because solar radiation peaks at around midday, a time when most people prepare lunch, solar thermal applications for cooking can coincide with demand. Solar thermal water heating systems are already in use by a few health centres, mission centres and a few households but require up-scaling and broadening the application to other facilities such as boarding schools where demand for firewood or electricity for cooking and water heating is high. Dissemination of solar cookers to households is being promoted by organisations such as Care and Support Network but their applications remain limited and the impact is overlooked at country level.

\subsection{Wind Energy}

Figure 8 shows a plot of monthly mean wind speed, at $2 \mathrm{~m}$ height, between Jan 2005 and December 2008 for five selected stations; Chitipa from the north, Nkhotakota and Salima from the central, and Chileka and Ngabu from the south of Malawi. It can be seen from Figure 8 that for the five stations the monthly mean wind speeds are mostly above $2 \mathrm{~m} / \mathrm{s}$. It should also be noted that wind speeds peak in July until October and remain above $3 \mathrm{~m} / \mathrm{s}$ during this period. The peak wind speeds coincide with a time when rivers' levels and the water table have gone down necessitating water pumping for household water supply and agricultural irrigation, and when temperatures are high necessitating space cooling; thus there is high probability of wind energy generation coinciding with demand. 


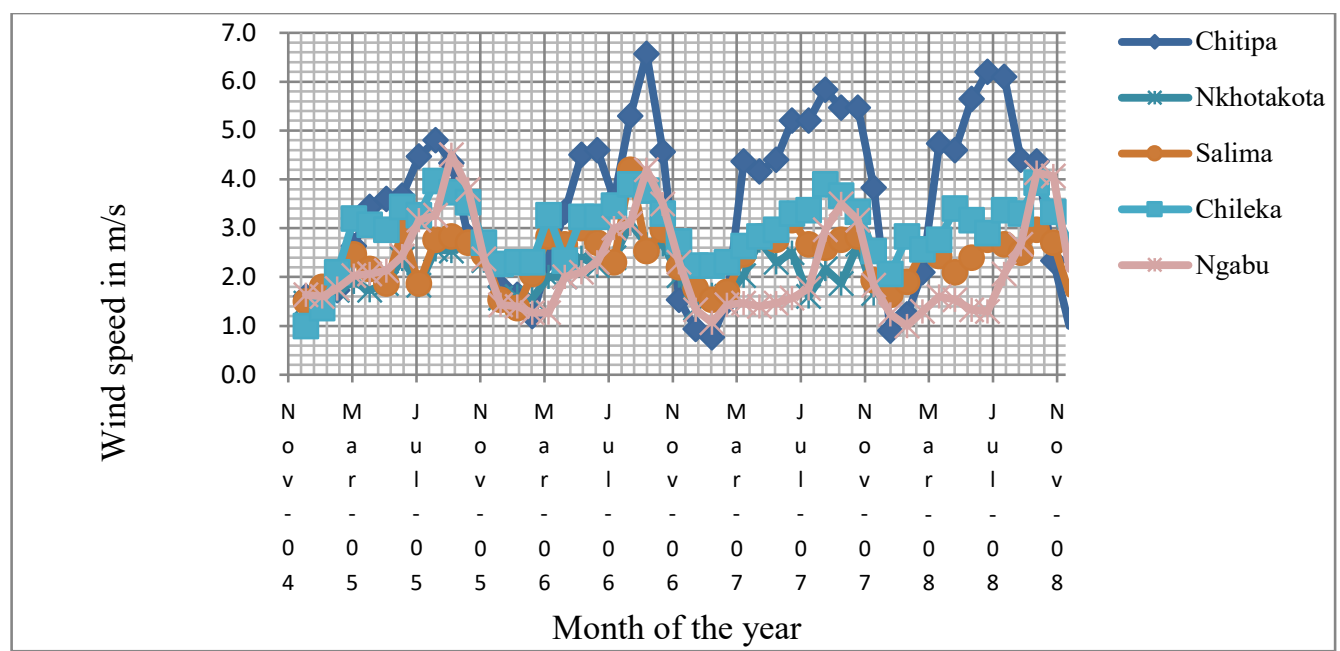

Figure 8: Monthly Average Wind Speeds at $2 \mathrm{~m}$ height for five selected stations in Malawi - based on wind data from the Department of Climate Change and Meteorological Services

The wind speeds shown in Figure 8 are viable for mechanical water pumping and for small scale electricity generation probably at hub heights of more than $10 \mathrm{~m}$ above the ground due to minimised sheltering effects and reduced effects of terrain roughness at higher heights; notwithstanding that further analysis using, for example, the Weibull distribution and hourly wind speed data would be ideal to calculate achievable capacity factors for the potential wind energy systems. Comprehensive countrywide wind resource mapping is also required due to the unreliability and uncertainties of wind speed measurement at $2 \mathrm{~m}$ height in the majority of the country's weather stations; only 3 out of 22 weather stations take wind measurements at $10 \mathrm{~m}$ height [18]. The major development in the Malawi's wind energy is the work of the Malawi Renewable Energy Acceleration Programme (MREAP) which identified two sites for potential wind farms in Mzimba and Rumphi districts by use of WRF Mesoscale Modelling and constraints mapping [18]; installation of wind masts for detailed wind speed measurements at the identified sites was planned for April 2013. Until 2013, government installs small wind turbines to a capacity of $10 \mathrm{~kW}$ as part of hybrid systems with solar PV for rural electrification projects; small turbines and mechanical systems are also used for electricity generation and water pumping respectively by a few households and a few institutions.

\subsection{Biomass Energy}

Malawi produces over 7 million tonnes of both crop residues and livestock dung. .

Table 3 and Table 4 show estimates of potential energy from crop residues and livestock dung respectively.

Table 3: Potential Energy from Agriculture Residues

\begin{tabular}{|l|r|l|l|l|r|r|}
\hline Crop & $\begin{array}{l}\text { Annual } \\
\text { production } \\
\text { (MT) }[19,20]\end{array}$ & $\begin{array}{l}\text { Residue to } \\
\text { product ratio } \\
\text { (RPR) [21, 22] }\end{array}$ & $\begin{array}{l}\text { Residue type } \\
{[21,22]}\end{array}$ & $\begin{array}{l}\text { Annual crop } \\
\text { residues } \\
\text { (MT) }\end{array}$ & $\begin{array}{l}\text { Potential } \\
\text { heating energy } \\
\text { (GJ/annum) }\end{array}$ \\
\hline Maize & $3,900,000$ & 1.5 & Stalk & $5,850,000$ & 90,558 \\
\hline Tobacco & 138,000 & 1 & Stalk & 138,000 & 2,222 \\
\hline Coffee & 1,500 & 2.1 & Husk & 3,150 & 40 \\
\hline Rice & 79,000 & 1.5 & Straw & 118,500 & 1,844 \\
\hline Cassava & $4,300,000$ & 0.2 & Stalk & 860,000 & 15,050 \\
\hline Cotton & 32,550 & 3.5 & Straw & 113,925 & 2,039 \\
\hline Total & $\mathbf{8 , 4 5 1 , 0 5 0}$ & & & $\mathbf{7 , 0 8 3 , 5 7 5}$ & $\mathbf{1 1 1 , 7 5 2}$ \\
\hline
\end{tabular}

a Potential heating energy is calculated using heating values of the crop residues from [21, 22, 23, 24, 25, 26] 
Table 4: Potential Energy from Livestock Dung

\begin{tabular}{|c|c|c|c|c|}
\hline $\begin{array}{l}\text { Livestock } \\
\text { Type }\end{array}$ & Populations [27] & $\begin{array}{l}\text { Potential dung } \\
\text { production } \\
\text { (Tonnes/annum) }^{\mathrm{a}}\end{array}$ & $\begin{array}{l}\text { Potential biogas } \\
\text { production } \\
\left(1000 \mathrm{~m}^{3} / \text { annum }\right)^{\mathrm{a}}\end{array}$ & $\begin{array}{c}\text { Potential energy } \\
\text { (GJ/annum) }\end{array}$ \\
\hline Cattle & $1,110,560$ & $3,242,835$ & 74,585 & 1,611 \\
\hline Goats & $4,442,907$ & $1,621,661$ & 25,947 & 560 \\
\hline Sheep & 228,649 & 83,457 & 1,335 & 29 \\
\hline Pigs & $2,160,670$ & $1,577,289$ & 63,092 & 1,363 \\
\hline Chickens & $44,672,086$ & $1,304,425$ & 847,876 & 18,314 \\
\hline Ducks & $1,014,869$ & 29,634 & 19,262 & 416 \\
\hline Rabbits & $1,022,864$ & 57,280 & 10,649 & 230 \\
\hline Guinea Fowls & $1,350,585$ & 39,437 & 25,634 & 554 \\
\hline Turkey & 145,486 & 4,248 & 2,761 & 60 \\
\hline Total & $56,148,676$ & $7,960,267$ & $1,071,142$ & 23,137 \\
\hline
\end{tabular}

${ }^{a}$ Potential dung and biogas production including the potential heating energies were calculated using dung and biogas factors, and heating value of $21.6 \mathrm{MJ}$ for biogas from $[28,29]$.

Crop residues can be compressed into briquettes or pellets for use in improved cookstoves for heating and cooking. Crop residues, at 15 percent conversion efficiency for biomass in improved cookstoves [30], can provide up to $16,762 \mathrm{GJ}$ of energy per annum, while biogas can provide up to $6,941 \mathrm{GJ}$ at 30 per cent biogas stove efficiency $[31,32]$. There is also potential for biogas from household and industrial waste which at present is left to decay in open dump sites. Potential energy recovery processes for the biomass resources produced in Malawi are shown in Figure 9.

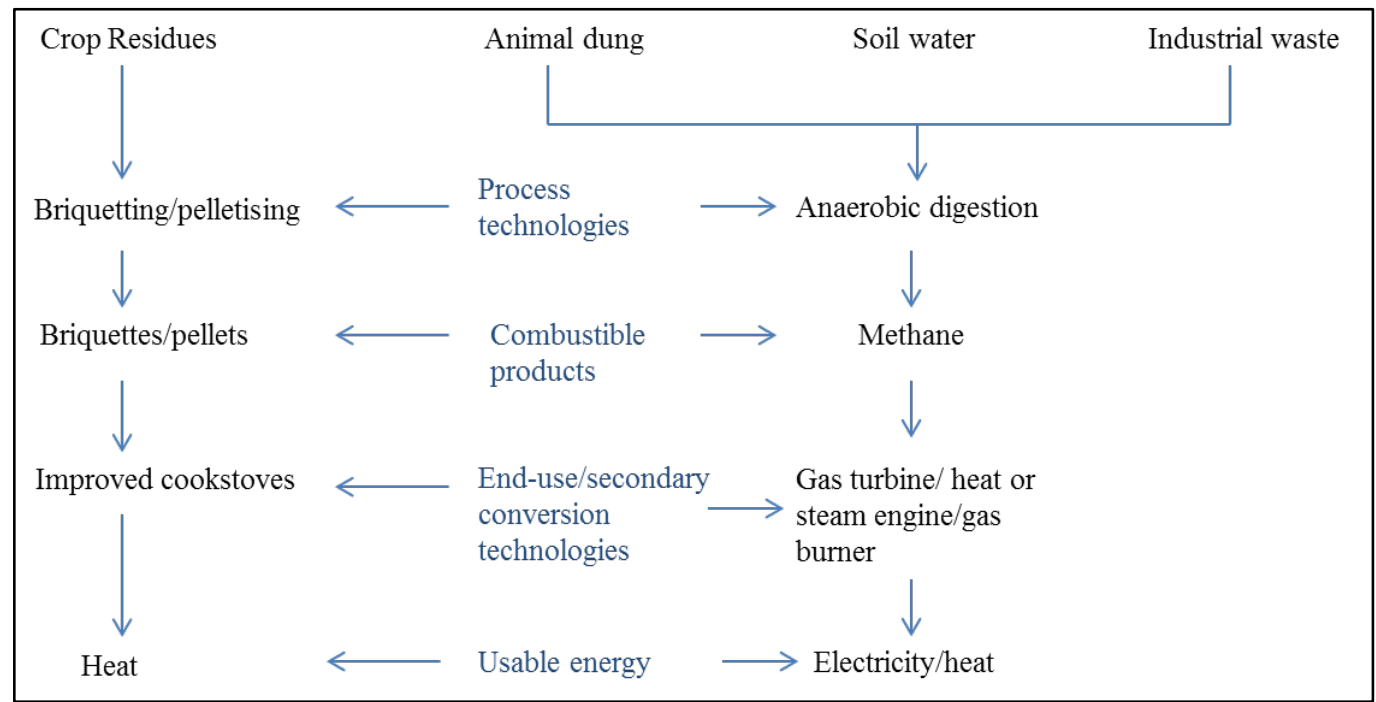

Figure 9: Viable Energy Conversion Routes for Malawi's Biomass (own illustration)

Malawi also produces a significant quantity of forest residues from forest plantations. The plantations were established in the1960s when it became apparent that the indigenous forest resources would not sustain the local and export need for timber. In total the Malawi Government owns 73,000 hectares of timber plantations and about 26000 square kilometres of indigenous forest reserves [33,34]. About 68,000 hectares of the timber plantations are planted with pine trees, with a few pockets of cypress and cedar tree species; the remaining plantation areas are under eucalyptus aimed at providing fuel wood and poles [33]. Although there is restriction of access into these forest plantations, until recently, dead trees were being collected as firewood free of charge. In areas where forest plantations are being harvested for timber production, forest residues have become a major energy resource with most of it being transported long distances for selling in urban centres. Mostly, during harvesting of mature stands of trees for timber production, saw millers are interested in particular portions of a stand to meet specific requirements. As a result almost one-third of the tree remains in the field as residues when the trees are harvested using efficient equipment [35]. In the Malawi's Viphya plantations, the largest forest 
plantation in east and southern Africa, covering about 53000 hectares [33]; it is estimated that $75 \%$ to $80 \%$ of a tree sawn by the small scale sawyers remains in the field. These residues include tops, branches, barks and stumps. Figure 10 shows a stack of tops from a single tree and Figure 11 shows a stack of semi round barks loaded for disposal after the logs are extracted in the Viphya Plantations.

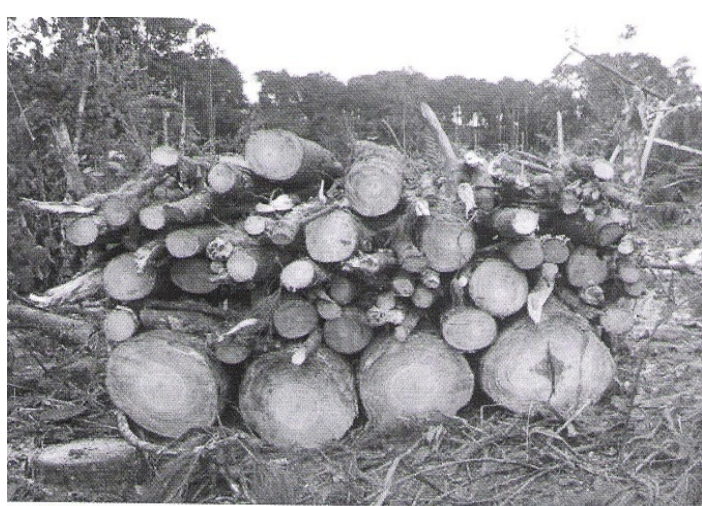

Figure 10: Stack of Residues from a Single Tree after logs have been Extracted.

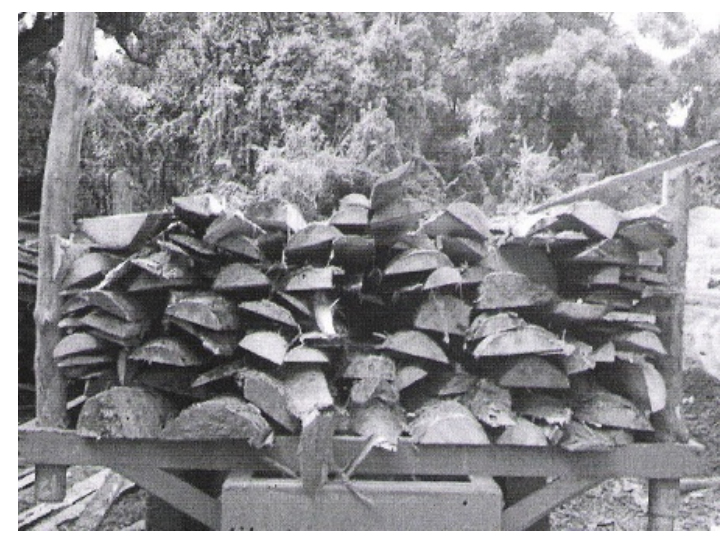

Figure 11: Semi Round Planks (barks) Loaded for Disposal

Each hectare in the Viphya plantations consists of 1,000 stands of pine trees. With the current harvesting practice, a minimum of 6 tonnes of barks are produced and left on the field as residues [36]. RAIPLY, which has a concession with the Malawi Government for harvesting 20000 hectares of the Viphya Plantations, harvests 200 hectares from the concessional area per year. $450 \mathrm{~m}^{3}$ of wood are processed per day from which $225 \mathrm{~m}^{3}$ of wood wastes are generated. In one year RAIPLY generates $61875 \mathrm{~m}^{3}$ of wood residues. If the forest residues were used to generate electricity, a 3.5 MWe power plant could sustainably be supplied with the residues throughout a year; this figure can be extended up to over 20 years if trees' harvesting is properly matched with replanting taking into account the maturity age of 25-30 years for pine trees. The other residue that is available in large quantities in forest plantations in Malawi but remains under-utilised is saw dust. Saw dust is a potential raw material for production of briquettes and pellets. Yet, saw dust from timber production and primary and secondary wood processing industries is left rotting or just set on fire. At the rate of $450 \mathrm{~m}^{3} /$ day of fresh wood being processed into timber, there is untapped potential of producing briquettes from the saw dust which could reduce demand for charcoal and firewood.

Despite the availability of the enormous biomass resource there are challenges to its utilisation. Transportation logistics are difficult due to poor road infrastructure in some of the biomass producing areas, especially in the rainy season. Collection of dung and crop residues is also an issue due, in part, to the free-range system of livestock farming by many farmers and sparsely distributed smallholder farmers, each farmer owning a small number of animals and producing small quantities of crops. Studies in other countries indicate that availability factors of the livestock dung for energy production can range from 0.05 to 0.8 [29] depending on the type of livestock and the livestock husbandry practices. 
Some of the efforts to promote the utilisation of non-traditional biomass include promotion of energy efficient wood stoves by the Program for Biomass Energy Conservation (ProBEC), now phased out in 2010; promotion of biomass briquettes through training of briquette producers by the Government's Promotion for Alternative Energy Sources Project (PAESP); construction of household biogas digesters by Mzuzu University; and promotion of biogas digesters by the Malawi Renewable Energy Acceleration Programme (MREAP).

\subsection{Hydropower}

Malawi has $1.34 \mathrm{GW}$ of unexploited hydropower from rivers spread across the country [37]; which is four times the installed capacity of hydro generation in 2012. Figure 12 shows the distribution hydro potential in the country and projected time frames for development of the sites. It should be noted that the 64MW Kapichira Phase II indicated in Figure 12 is in progress and is expected to be commissioned in the last quarter of 2013. Also, half of the untapped hydro resource is on the Shire River; with 98 percent of Malawi's electricity already generated on the Shire, development of additional hydroelectricity schemes on the river should be justified by detailed risk analysis as one way of ensuring energy security in the country; otherwise sites located on other rivers should be considered with priority in future development of hydro generation schemes.

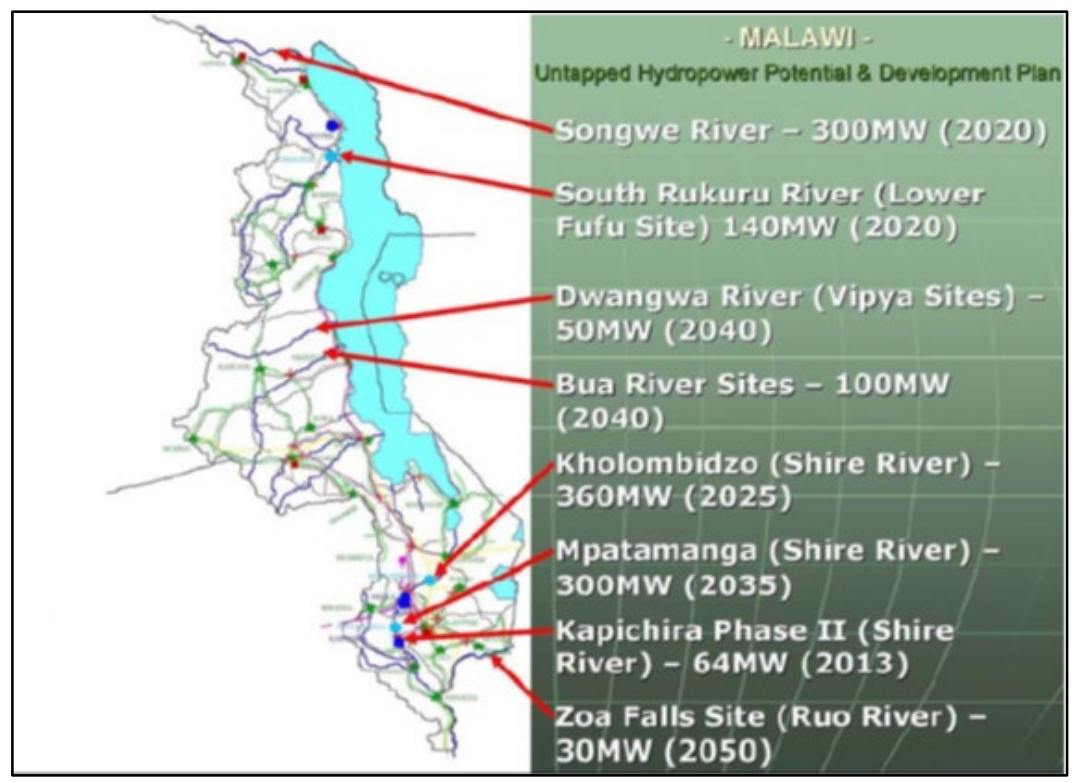

Figure 12: Untapped Hydro Power Potentail in Malawi [37]

5.5 Geothermal Energy

A recent geothermal exploration by the Department of Energy Studies at Mzuzu University shows that there are over 50 known hot springs in Malawi with 18 hot springs having a surface average temperature of above $50^{\circ} \mathrm{C}$. A selection of the hot springs is shown in Table $\mathbf{5}$.

Table 5: A Selection of Geothermal Sites in Malawi ${ }^{2}$

\begin{tabular}{|c|c|c|}
\hline Name & District of Location & $\begin{array}{c}\text { Ave surface-water } \\
\text { Temp in }{ }^{\circ} \mathrm{C}\end{array}$ \\
\hline Mphizi & Rumphi & 82 \\
\hline Chiwi & Nkhotakota & 76 \\
\hline Mtomdoro & Nkata Bay & 72 \\
\hline Mawira 1 & Nkhotakota & 67 \\
\hline Mawira 3 & Nkhotakota & 65 \\
\hline Mawira 4 & Nkhotakota & 64 \\
\hline Chombo & Nkhotakota & 64 \\
\hline Mawira 5 & Nkhotakota & 63 \\
\hline Ling'ona & Nkhotakota & 61 \\
\hline
\end{tabular}

\footnotetext{
${ }^{2}$ List of hot springs was provided by K.T. Gondwe, one of the co-authors of this paper, who carried out the geothermal exploration study.
} 


\begin{tabular}{|c|c|c|}
\hline Ngara 1 & Karonga & 59 \\
\hline Ngara 2 & Karonga & 55 \\
\hline July village & Chikwawa & 55 \\
\hline Chipwidzi 1 & Nkhotakota & 54 \\
\hline Mukungwi & Karonga & 52 \\
\hline Mwankenja 2 & Karonga & 50.5 \\
\hline Mwankenja 1 & Karonga & 50 \\
\hline Mawira 2 & Nkhotakota & 50 \\
\hline Sitima & Balaka & 50 \\
\hline
\end{tabular}

Using surface temperature, $T s$, temperature (Tz) of a hot spring at a depth $z$ for a temperature gradient $G$, can be calculated using $T z=T s+G z[38,39]$; further work is in progress to determine ground temperatures of the geothermal sites in order to determine potential of electricity generation and other applications. Studies $[40,38$, 39] recommend generating electricity from geothermal sites with temperatures above $150^{\circ} \mathrm{C}$ using Rankine cycle steam turbines; and extracting heat for industrial processes and/or space heating or cooling using ground heat pumps from sites with temperatures between $40^{\circ} \mathrm{C}$ and $150^{\circ} \mathrm{C}$. It can be seen that, even without drilling into the ground, the surface-water temperatures at the sites listed in Table $\mathbf{5}$ are viable for process and space heating. However, in developing the geothermal energy resources, both electricity generation geothermal plants and geothermal source heat pumps have to be evaluated based on some of the factors outlined below.

i. The easiness of transporting the produced energy to load centres:

Electricity can easily be transported over long distances compared to heat which presents challenges at

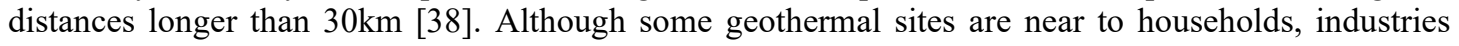
where process heating could be important are located hundreds of kilometres away from the potential geothermal sites.

ii. Efficiency and capacity factors:

Organic Rankine Cycle (ORC) turbines used for geothermal electricity generation typically operate with efficiencies ranging from 10 to 17 percent [39] whereas ground source heat pumps operate with efficiencies, usually termed as Coefficient of Performance, COP, ranging from 300 to 600 percent ${ }^{3}$ [40]. However, efficiency has to be considered together with capacity factor noting that geothermal heat pumps require electricity or fuel-driven engines to operate, thus their capacity factor may be affected by the availability of the primary energy driving them. On the other hand, capacity factors of over 90 per cent are reported for geothermal plants generating electricity [38].

iii. Capital costs:

Electricity generation from the geothermal sites would require drilling to depths to obtain high temperatures technically feasible for electricity generation in addition to capital costs of the ORC turbines, transmission line connecting to grid network or mini-grid network for local distribution of electricity. On the other hand, heat for industrial processes or space heating could be exploited on the surface and major costs would be on the heat distribution network, heat pumps and the electrical energy for driving the heat pumps. The electrical energy for the heat pumps can create challenges if there is no nearby grid-network access point; nevertheless, the heat pumps could be cost-effective compared to direct use, for heating or cooling, of the electrical energy that drives them: Any industry considering relocating close to the geothermal sites must critically evaluate this issue.

The geothermal resource in Malawi remains insignificantly tapped; a few hot springs are used for supplying hot water to nearby villages for domestic use. In other sites, people use the hot water at the pools directly for bathing and washing clothes.

\section{Challenges for the Energy Supply Industry in Malawi}

Challenges affecting the energy supply industry of Malawi include but one not limited to increasing energydemand, lack of finance for large scale energy projects, shortage of trained human resource, poor governance, weak legislation and weak regulatory framework. The challenges are discussed as follows.

\footnotetext{
${ }^{3}$ It means for every unit of energy that drives the pump, the output is 3-6 times; for example, 100kWh from electricity driving the heat pump would deliver between $300-600 \mathrm{kWh}$ of heat from the ground heat source.
} 
6.1 Increasing Energy-Demand

In the late 1990s Malawi's per capita energy consumption was at 12.5GJ which compared unfavourably with the average per capita of $80 \mathrm{GJ}$ and $200 \mathrm{GJ}$ for middle-income and high income countries respectively [9]. The recurrent energy crises of electricity blackouts and fuel wood shortages and the fossil fuel shortage in 2011 and 2012 are evidence that the situation has not improved. For example, with an installed capacity of $288 \mathrm{MW}$ of grid power, each person has a share of $18 \mathrm{~W}$ i.e. $163 \mathrm{kWh}$ per person per annum assuming power is $\mathrm{ON}$ all the time; as of 2011 the average household electricity consumption in Malawi remained at $111 \mathrm{kWh}$ per annum [4]. This consumption is 100 times less than the over $2000 \mathrm{~W}$ threshold of electricity for each person and/or each household in developed countries [38, 41]. In view of the low energy per capita consumption and accounting for the positive correlation between electricity and energy consumption with GDP $[42,43]$ it is clear that growing the economy and improving living standards in Malawi will result in increased energy demand in the following areas:

i. Irrigation agriculture;

ii. Lighting, cooking, heating, information and communication technologies, and entertainment;

iii. Health services;

iv. Transport services;

v. Agro-processing and manufacturing; and

vi. Water supply and sanitation.

For example, projections by the Department of Energy Affairs using the IAEA's Model for Analysis of Energy and Electricity Demand (MAED) show a fivefold increase of electricity-demand alone by 2030 as shown in Figure 13.

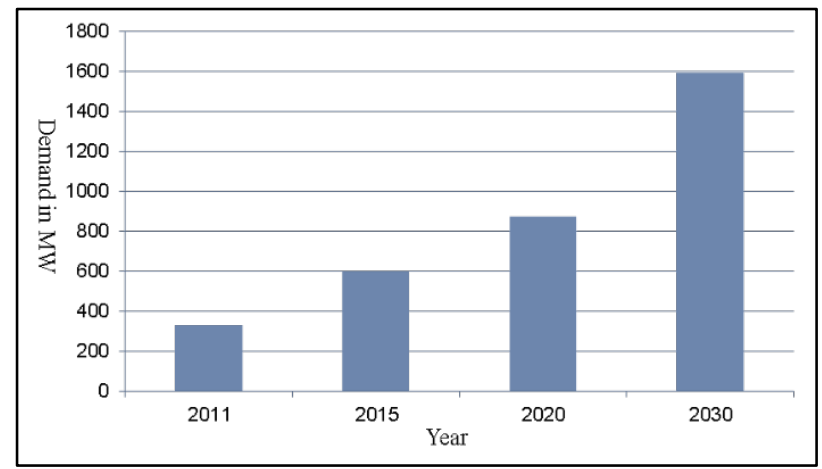

Figure 13: Malawi’s Electricity Demand Projection- data source [14]

Despite that MAED undertakes detailed analyses of socio-economic demography as outlined in [44], the projections shown in Figure 13 are likely to have been underestimated considering Malawi's low access to electricity which was at 8 per cent in 2010; load shedding carried out by the country's electricity utility company; people's tendency to buy and use more electrical appliances when they have access to electricity; and the unmet electricity demand of industries operating off-grid using independent diesel generators because of the country's low electricity generation capacity. If the transmission and distribution network were accessible to every household, capital costs for connection to the grid were affordable to the majority of households, and the installed capacity of electricity generation were adequate, the demand projections should show a high growthrate at the beginning slowing down with time as households reach saturation of household electrical appliances and industrialisation fully realised, leaving population growth rate as the only major factor dictating energy demand. With the country's population growing, estimated at 15 million in 2011 from 13million in 2008, means that the demand for firewood for cooking and many other energy services is growing significantly and therefore satisfying the increasing energy demand requires innovative sustainable energy supply programmes.

\subsection{Financing}

Malawi's weak economy constrains the financing of large scale energy projects. Even small scale energy projects suffer from uncertainties of financing for operation and maintenance costs. Small and medium scale projects are funded from fuel levies which are in turn constrained by the low fossil fuel per capita consumption due to limited number of vehicles and limited industrial activities in the country. So most of the large-scale projects depend on financing from multilateral organisations and donations from external governments; this is not sustainable considering the global economic crisis affecting potential development partners to Malawi. Sometimes, it also occurs that external funding has many conditions attached, particularly on governance and human rights issues, some of which conflict with the social and cultural heritage of Malawi, raising fears on the sustainability of funding from international development partners especially if Malawi decides to defend its 
position on social and cultural heritage. For example, there have been cases where external governments have frozen funding for projects because of Malawi's position on minority rights especially gay rights which the majority of Malawians criticise that it does not reflect the cultural of Malawi, but the concerned development partners argued that the actual reason was poor governance and they claimed that the Malawi Government was misinforming its citizens. For the Government's Barrier Removal to Renewable Energy Projects funded by the Global Environment Facility (GEF), one of the objectives that were not fully addressed was the identification of viable financing mechanisms for renewable energy technologies; and this continues to be a challenge for the diffusion of renewable energy technologies in Malawi.

\subsection{Human Resource and Training}

Malawi has a limited number of trained personnel for development, implementation, operation and maintenance of large scale energy systems. Large scale energy projects are usually contracted to external companies. The situation is complex in the delivery of renewable energy technologies which are relatively new. Although energy programmes are offered in vocational and higher education institutions, the education institutions are incapacitated in research and laboratory equipment thus affecting the quality of technical training delivered. For example, the lack of local technical expertise is cited as one of the reason that resulted in 50 percent of the 5,000 Solar Home Systems installed since 2000 becoming non-operative by 2003 [9]. This is also evidenced by the importation of human resource during development and maintenance of energy systems in the country; and sometimes system components are sent to other countries for maintenance. The financial implications associated with logistics of sourcing trained human resource from other countries to install and/or maintain renewable energy systems in Malawi; for example, for commercial wind farms, is potentially over MK36,000,00.00 ( $£ 60,000.00)$ annually per MW of installed capacity [18]. And as a result of the weak economy, there is high likelihood of renewable energy systems being affected by delayed maintenance leading to lower capacity factors or performance ratios thereby reducing the lifecycle benefits of the systems.

\subsection{Regulation and Governance}

The Malawi Energy Regulatory Authority (MERA) is mandated to regulate the energy sector [45] using the Energy Laws as the major the legal instruments; while the Malawi Bureau of Standards (MBS) enforces adherence to standards for, but not limited to, energy systems installation. However, independence of the bodies is not clear especially when implementing big projects led by government and when enforcing policies that may affect political alignments of people. It is feared that systems can be hastily certified and commissioned to register political milestones while compromising on quality. Other conflicts arise between policies of different government sectors because of lack of coordination. For example, the agriculture sector would tolerate cultivation along the river banks as one way of supplementing rain-fed agriculture to enhance food security, but this could disadvantage energy generation because of resultant siltation in rivers that consequently affects turbines downstream: The Electricity Supply Corporation of Malawi shuts down its machines every year to desilt its dam; part of the siltation could be as a result of unregulated and/or unmonitored cultivation along the river banks.

\section{A PESTLE Analysis for the Delivery of Renewable Energy Systems}

Basu (2004) [46] discusses how economic, social, political, legal and environmental (PESTLE) factors should be carefully considered when implementing projects. Based on the PESTLE framework, the factors that need to be considered to ensure sustainable delivery of renewable energy technologies in Malawi are as follows.

\subsection{Political and Legal Factors}

The tax waiver on importation of renewable energy technology components offers opportunity to improve renewables penetration in Malawi; however, enforcement of legal instruments is required to address:

i. Potential of abuse of tax waiver by retailers: Surveys carried out in some parts of Malawi show that the tax waiver on importation of renewable energy technologies is not reflected in the retail prices and as a result renewable energy technologies remain at prohibitive prices.

ii. Importation and implementation of substandard systems, which damages the reputation of renewable energy technologies in the country: There have been cases of systems; particularly battery based solar PV systems, becoming non-operative within one year of implementation. This is, in one part, as a result of lack of quality checks on the imported system components due to unavailability of testing centres for renewable energy technologies in the country. A testing centre was established at Mzuzu University in 2003 but until 2013 it has not been operational. Lack of independent quality-checks before commissioning of renewable energy systems also contribute to the implementation of substandard systems; which can be addressed by strong coordination among the energy sector regulatory bodies, bureau of standards, and specialised private sector consultants. 
In addition, there is also likelihood of social enterprise organisations disseminating technologies to households in rural areas overpricing technologies on the basis of overhead costs and yet claim that they do not charge interest on the technologies' retail price. To minimise this likelihood, appropriate legal instruments are critical.

In Western countries, policies obliging energy suppliers to source part of their energy from renewables have been key drivers of renewable energy technologies. Although 99 percent of Malawi's grid electricity is generated from renewable sources; a similar approach to renewables obligation in the West could be applied to increase the application of some of the new renewable energy technologies in Malawi. For example, a policy could be laid out obliging institutions such as boarding secondary schools and prisons to source part of their energy for cooking from biogas digesters which could run on human waste or from solar thermal systems thereby reducing the demand for firewood and/or electricity for cooking by secondary schools and other facilities. Phwezi secondary school remained the only school using biogas for cooking as of 2013; the school has been using the biogas generated from human waste for over 12 years.

Recently, it has also been observed that politicians distribute renewable energy technologies for free to households probably for campaigning reasons. Whilst this practice can lead to improved adoption and diffusion of renewable energy technologies, providing funds to local retailers to subsidise the technologies and putting in place appropriate legislation could result in increased number of beneficiaries and enhanced ownership of systems; which would probably be a more sustainable approach.

\subsection{Social, Technology, Economic Factors}

Studies, for example in [42], showing correlation between electricity consumption and quality of living, can influence majority of renewable energy projects to put emphasis on providing for electricity. Although electricity is considered fundamental for modern living it may not the appropriate form of energy for meeting certain energy needs like cooking and heating [47]. Following is a discussion of some of the technology and socio-economic factors that need to be considered when delivering renewable energy technologies.

\subsubsection{Energy Needs, Associated End-use Appliances and Social Acceptability}

With firewood becoming scarcer, renewable energy technologies for heating like solar cookers, biomass briquettes, and biogas could be more important to some communities than small scale solar PV and /or wind energy technologies designed only for lighting. Therefore interventions have to be identified based on objective assessments of social needs and priorities in the light of viable technologies based on energy resources available in communities, and the prevailing economic conditions.

It is also important to recognise that systems sustainability especially for community based renewable energy systems requires enhancing ownership whereby individuals should support and ensure security of systems even when they do not individually own the energy systems assets. However, people usually support technologies that can reliably meet their priority needs, offering relative economic advantages, protecting their social security and enhancing their society pride and status; so the practice of organisations tending to finance projects that fulfil their own objectives, for example meeting the emission targets at a low cost per unit of mitigated emissions rather than based on objective assessment of the priorities of communities has to be properly evaluated when implementing projects.

Also, the flexibility of electricity to be easily converted to many forms of energy can make electricity-outputbased systems a better choice compared to thermal or mechanical power systems, but sometimes decisions on the systems is a result of misconceptions and lack of awareness of available options. For example, instead of installing solar PV systems that supply power to electric geysers; solar thermal water heaters can be installed to offset the water-heating demand consequently reducing the overall capital costs for a renewable energy system and offering a combined higher efficiency. Likewise, in certain cases, it is cheaper to use rechargeable solar lanterns or mini-PV with LED lights to provide lighting whilst conventional PV modules provide power for other electrical appliances such as a television instead of using conventional PV systems to provide power for all electric loads in a property. Also, if the aim of a project is to reduce demand for charcoal or firewood, it should be noted that providing electricity does not automatically lead people to using electricity for cooking; some people may not be able to afford to purchase electric cooking appliances yet they could afford to purchase an improved cookstove thereby making biomass briquetting technologies, for example, more appropriate. Depending on design, biogas digesters may require labour and time for feed collection (e.g. dung), mixing of influent slurry, and fetching water (if no water point is available nearby); this could be a source of drudgery sometimes more than the work involved in searching for fuel wood consequently putting off people from using the technology. Knowledge of food preparation methods is also crucial for identifying appropriate technology for an intervention: For example, parabolic dish solar cookers may only be ergonomically good for preparing 
rice, potatoes, hot water; but not for Nsima which is the staple food in Malawi. Preparation on Nsima involves continuous physical handling of a pot. Figure 14 shows a typical design of a parabolic dish solar cooker.

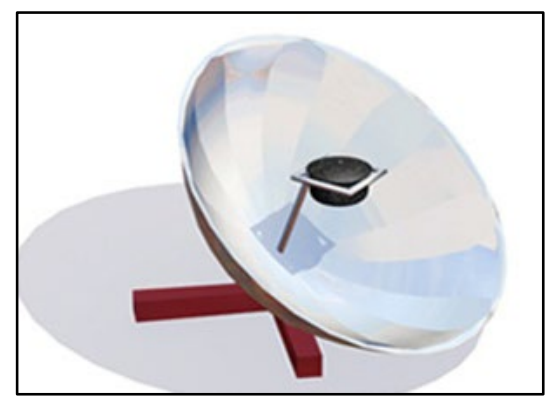

Figure 14: Typical design of Parabolic Dish Solar Cooker (adapted from google images)

As shown in Figure 14, the solar cooker requires that it has a large surface area to yield enough energy but allowing comfortable access to the pot at the focal point by the user; and should have mechanical strength to stand the cyclic loads associated with Nsima preparation. In addition, minimising the shade from the user as well as reducing the discomfort of the user for having to cook in the open and be subjected to the sun could be a challenge. Prevailing socioeconomic conditions are therefore crucial to the identification of appropriate renewable energy technologies for communities.

\subsubsection{Ground Based Centralised Grid Connected PV Systems versus Roof Based Grid Connected PV Systems}

Centralised grid-connected or systems operated in a utility model have the potential of both technical and economic sustainability; utility companies are likely to have the technical skills to maintain the systems, and have high likelihood to access funds from financing institutions, and recovery of the investment costs would be achieved from tariffs paid by connected adopters. However, because of the requirement for a large area that may necessitate land tenure reforms which could result to loss of biodiversity; installation of grid connected solar PV on existing large area roofs of permanent buildings should be considered to offset the land requirement of ground based centralised system.

\subsubsection{Locally Manufactured Systems versus High-tech Imported Systems}

Wherever possible, imported systems should be avoided: supply chain management of spare parts, and technical skills for maintenance of imported systems can affect systems reliability. The stability of local currency against other currencies may also compound the volatility of the economics and viability of the systems. It would be cost effective to use simple systems produced by local companies which makes it easy to source local maintenance expertise and spares when systems fail. A deliberate policy framework obliging potential adopters of renewable energy technologies to procure local systems where possible would improve the current practice whereby there is a tendency of people having more trust in imported systems than local systems. For example, despite the availability of companies that locally manufactured solar water heaters, intuitions including government had continued to install imported solar water heaters leading to the collapse of the local manufacturing which would have been contributing to the economic growth of the country through creation of direct employment and indirect employment in the associated supply chain industry.

\subsection{Environmental Factors}

The need for the mitigation against climate change can make some developers restrict environmental concerns to emissions. Although renewable energy technologies have potential to reduce emissions, their implementation can have local environmental impacts. For example effluent from biogas digesters; particulates from biomass combustion; noise and interference with communication systems from wind turbines [48]; and landscape changes can cause negative effects on the local environment. Therefore consideration should be given to full environmental impact assessment and appropriate environmental management systems should be designed for the potential impacts. Furthermore, although some financers place emphasis on carbon emission savings when funding energy technologies, government and/or local institutions should be able to weight appropriately the criteria for identifying an energy technology based on local definition of sustainability and sustainable livelihoods of communities: sustainability is founded upon the concept of sustainable development, defined as "development that meets the needs of current generations without compromising the ability of future generations to meet their own needs [49]"; whilst sustainable livelihoods is defined as "a livelihood comprises the capabilities, assets (including both material and social resources) and activities required for a means of living. A livelihood is sustainable when it can cope with and recover from stresses and shocks; maintain or enhance its capabilities and assets, while not undermining the natural resource base" [50]. From the two definitions there is a risk, especially for developing countries, of one placing more emphasis on the meaning of 
"without compromising the ability of future generations to meet their own needs" and the meaning of "while not undermining the natural resource base" respectively without weighting appropriately the scope and contextual definition of "meeting current needs" and "enhancement of people's capabilities and assets" considering the leapfrog of energy infrastructure required for poor communities.

\section{Conclusion}

The energy situation of Malawi has been outlined and the challenges for the country's energy sector including a PESTLE framework for delivery of renewable energy technologies have been discussed. Further to the energy balance leaning towards traditional biomass, the energy supply in Malawi is inadequate and unreliable leading to limited economic growth. However, the country is endowed with renewable energy resources which can improve the energy security for the country and improve economic activity. Solar, biomass, and hydropower are the most certain renewable energy resources that can contribute significantly to the energy supply of the country but further resource mapping work is required for comprehensive determination of geothermal and wind resources. Although the Malawi National Energy Policy clearly lays out the steps towards improving the country's energy situation; unreliable financing mechanisms for large scale energy projects, shortage of trained human resource, lack of coordination among local institutions; unclear regulation framework and sometimes political governance impede the sustainable execution of energy projects. From the discussion presented in this paper it is clear that huge investment and a holistic approach are crucial to strengthen Malawi's energy sector; which requires radical political and governance decisions.

\section{References}

[1] Malawi Government, "The Warm Heart of Africa," 2011. [Online]. Available: http://www.malawi.gov.mw/. [Accessed 8 November 2011].

[2] World Bank, "World Development Indicators - Malawi,” 2013. [Online]. Available: http://data.worldbank.org/country/malawi. [Accessed 21 May 2013].

[3] National Statistics Office of Malawi, "Malawi Census Main Report," National Statistics Office, Zomba, 2008.

[4] Millennium Challenge Account-Malawi, "Concept Paper for the Energy Sector," Malawi Government, Lilongwe, 2011.

[5] World Bank, "Malawi Country Brief," 2010. [Online]. Available: http://web.worldbank.org/WBSITE/EXTERNAL/COUNTRIES/AFRICAEXT/MALAWIEXT/0,,print:Y isCURL:Y menuPK:355882 pagePK:141132 piPK:141107 theSitePK:355870,00.htm. [Accessed 10 October 2011].

[6] Ministry of Development and Planning Cooperation, "2010 Malawi Millennium Development Goals Report," Malawi Government, Lilongwe, 2011.

[7] G. Gamula, L. Hui and W. Peng, "Development of Renewable Energy Technologies in Malawi," International Journal of Renewable Energy Technology Research, vol. 2, pp. 44-52, 2013.

[8] ESCOM, “Generation Capacity," 2011. [Online]. Available: http://www.escom.mw/power_generation.php . [Accessed 8 October 2011].

[9] Ministry of Energy and Mining, "National Energy Policy”, Malawi Government, Lilongwe, 2003.

[10] P. Kambewa and L. Chiwaula, "Biomass Energy Use in Malawi. A Background Paper Prepared for the International Institute for Environment and Development (IIED) for an International ESPA Workshop on Biomass Energy, Parliament House hotel, Edinburgh”, Zomba: Chancellor College, 2010.

[11] Department of Energy Affairs, "Promotion of Alternative Energy Sources Peroject Document", Ministry of Natural Resources, Energy and Mining, Lilongwe, 2006.

[12] O. Ezekwesili, O. Godron and J. Ghir, et al. "Project Appraisal Document for a Proposed Grant and a Proposed Credit to the Republic of Malawi for the Energy Sector Support Project," World Bank, 
Lilongwe, 2011.

[13] D. Brown, "Uranium Mining in Malawi," [Online]. Available:

http://uraniuminvestingnews.com/8029/uranium-mining-in-malawi.htm. [Accessed 31 January 2012].

[14] Malawi Government, “Vision 2020,” 2011. [Online]. Available: www.sdnp.org.mw. [Accessed 10 October 2011].

[15] M. Owen, K. Openshaw, R. Van der Plas, M. Matly and M. Hankins, "Malawi Biomass Energy Strategy," Malawi Government, Lilongwe, 2009.

[16] Department of Climate Change and Meteorological Services, "Solar Radiation Data", 2010.

[17] Ministry of Development Planning and Coorperaton , "Annual Economic Report," Malawi Government, Lilongwe, 2011.

[18] Sgurr Energy, "Inititial Feasibility Study and Nationwide Constraints Mapping," Malawi Renewable Energy Acceleration Programme, Glasgow, 2013.

[19] FAO, "Food Outlook Global Market Analysis," 2011. [Online]. Available: http://www.fao.org/docrep/014/a1981e/a1981e00.pdf. [Accessed 20 January 2012].

[20] US Department of Agriculture, "Malawi Agriculture Production Statistics," 2011. [Online]. Available: $\mathrm{http}: / / \mathrm{www}$. indexmundi.com/agriculture/?country=mw\&commodity=corn\&graph=production. [Accessed 20 January 2012].

[21] M. Duku, S. Gu and E. Hagan, "A Comprehensive Review of Biomass Resources and Biofuels Potentail in Ghana," Renewable and Sustainable Energy Reviews, vol. 15, no. 1, pp. 404-415, 2011.

[22] A. Eisentraut, "Sustainable Production of of Second-Generation Biofuels - Potentail and Perspectives in Major Economies and Developing Countries," IEA, Paris.

[23] A. Kumar, P. Purohit, S. Rana and T. Kandpal, "An Approach to the Estimation of the Value of Agriculture Residues Used as Biofuels,” Biomass Bioenergy, vol. 22, no. 3, pp. 195-203, 2002.

[24] M. Saenger, E. Hartge, J. Werther, T. Ogada and Z. Siagi, "Combustion of Coffee Husks," Renewable Energy, vol. 23, no. 1, pp. 103-121, 2001.

[25] A. Zabaniotou and O. Ioannidou, "Evaluation of Utilisation of Corn Stalks for Energy and carbon Material Production using Rapid Pyrolisis at High Temeprature," Fuel, vol. 87, no. 6, pp. 834-843, 2008.

[26] M. Acaroğlu and H. Aydoğan, "Biofuels Energy Sources and Future of Biofuels Energy in Turkey. Biomass Bioenergy," Biomass Bioenergy, vol. 36, pp. 69-76., 2012.

[27] "Livestock in Malawi,” 2011. [Online]. Available: http://livestockinmalawi.page.t1/Facts-andfigures.htm. [Accessed 25 January 2012].

[28] R. Arthur, M. Baidoo and E. Antwi, "Biogas as a Potential Renewable Energy Source: A Ghanaian Case Study.," Renewable Energy, vol. 36, no. 5, pp. 1510-1516, 2011.

[29] F. Batzias, D. Sidiras and E. Spyrou, "Evaluating Livestock Manures for Biogas Production: A GIS Based Method," Renewable Energy, vol. 30, no. 8, pp. 1161-1176. , 2005.

[30] ProBEC, "Saving Energy for the Future-Countries," [Online]. Available: http://www.probec.org/displaysection.php?czacc=\&zSelectedSectionID=sec1192750452. [Accessed 17 July 2012]. 
[31] I. Itodo, G. Agyo and Y. Yusuf, "Performance Evaluation of a Biogas Stove for Cooking in Nigeria.," Journal of Energy in Southern Africa, vol. 18, no. 3, pp. 14-18, 2007.

[32] K. Khandelwal and V. Gupta, "Popular Summary of the Test Reports on Biogas Stoves and Lamps Prepared by Testing Institutes in China, India and the Netherlands.," SNV; Netherlands, 2009.

[33] J. Luhanga, “The Timber Trade in Malawi," Southern Afrca Resource Watch, 2009.

[34] Department of Forestly in Juma, A.M., "Pondering over our Energy Future -Issues and Options in the Malawi Energy Sector," in Society of Malawi, Mzuzu, 2006.

[35] R. Sims, The Brilliance of Bioenergy - In Business and In Practice, First edition., James \& James (Science Publishers) Ltd., 2002.

[36] G. Chamayere, "Analysis of Sustainability of Supply of Forest Residues for Installation of Power Plant in Chikangawa Forest (unpublished),” Mzuzu University, Mzuzu, 2009.

[37] M. Gondwe, "Impacts on Generation, The Case of Malawi's Run-of River Hydro Power Schemes, Conference Attendance Report for the 6th International Conference on Hydropower : Hydropower Supporting other Renewables”, Blantyre: ESCOM, 2010.

[38] J. Twidell and T. Weir, "Geothermal Energy," in Renewable Energy Resources., Second edition., London and New York, Taylor \& Francis, 2006, pp. 471-488..

[39] R. Köse, "Research on the Generation of Electricity from the Geothermal Resources in Simav Region, Turkey. Renewable Energy,” Renewable Energy, vol. 30, no. 1, pp. 67-79, 2005.

[40] S. Self, B. Reddy and M. Rosen, "Geothermal Heat Pump Systems: Status Review and Comparison with Other Heating Options.," Applied Energy, 2012, in press, corrected proof.

[41] J. Morrow and J. Smith, "Switzerland and the 2000W Society,” Sustainability, vol. 1, no. 1, pp. 32-33, 2008.

[42] C. Jumbe, "Cointegration and Cuasality between Electricty and GDP: Emperical Evidence from Malawi,” Energy Economics, vol. 26, pp. 61-68, 2004.

[43] J. Samoilidis and C. Mitrolopulos, "Energy and Economic Growth in Industrialized Countries," Energy Economics, vol. 6, pp. 191-206, 1984.

[44] IEAE , "Computer Manual Series No. 18 - Model for Analysis of Energy and Electricity Demand (MAED-2),” 2006. [Online]. Available: http://www-pub.iaea.org/MTCD/publications/PDF/CMS18 _web.pdf. [Accessed 18 July 2012].

[45] Malawi Energy Regulatory Authority, "MERA Mandates," [Online]. Available: http://www.meramalawi.mw/mera/?q=content/mera-mandates. [Accessed 12 October 2011].

[46] R. Basu., "Tools for Analysis - PESTLE Analysis.," in Implementing Quality: A Practical Guide to Tools and Techniques, Fisrt edition., London, Thomson Learning, 2004, pp. 98-100.

[47] DFID, “Energy for the Poor-Underpinning the Millennium Development Goals,” DFID, London, 2002.

[48] J. Twidell and T. Weir, "Wind Power," in Renewable Energy Resources, Second ed., London and New Ork, Taylor \& Francis, 2006.

[49] United Nations, “Our Common Future,” United Nations, 1987.

[50] I. Scoones, “ Sustainable Rural Livelihoods, A Framework for Analysis.,” Institute of Development 
Studies, Brighton, , 1998. 